\title{
GREEN HYDROGEN CHARACTERISATION INITIATIVES: DEFINITIONS, STANDARDS, GUARANTEES OF ORIGIN, AND CHALLENGES
}

Anthony Velazquez Abad*, Paul E. Dodds

Institute for Sustainable Resources, University College London

* Corresponding author: 14 Upper Woburn Place, London WC1H ONN, UK.

\section{A.Velazquez@ucl.ac.uk}

\section{ABSTRACT}

Hydrogen can be produced from many different renewable and non-renewable feedstocks and technological pathways, with widely varying greenhouse gas emissions. For hydrogen to have a role in future low-carbon energy systems, it is necessary to demonstrate that it has sufficiently low carbon emissions. This paper explores how green hydrogen has been defined, reviews nascent green hydrogen characterisation initiatives, and highlights the main challenges that standards and guarantee of origin schemes must overcome to develop a market for green hydrogen.

Most existing green hydrogen initiatives are in Europe. In anticipation of a future market for green hydrogen, international standards are starting to be discussed by national and international standardisation organisations and policy makers. A range of approaches have been taken to defining green hydrogen and guarantees of origin. These vary on whether green hydrogen must be produced from renewable energy, on the boundaries of the carbon accounting system, the emission thresholds at which hydrogen is considered green, and on which feedstocks and production technologies are included in the scheme. Decisions on these 
factors are often influenced by other national and international standards, and the legal framework in which the green hydrogen supply chain operates.

\section{KEYWORDS}

Certification; guarantee of origin; green; hydrogen; standard; policy

\section{ABBREVIATIONS}

EECS European Energy Certificate System

GHG Greenhouse gases

GOs Guarantees of origin

ISC Independent sustainability criteria

MSW Municipal solid waste

RE Renewable energy

RED 2 Renewable Energy Directive 2018/2001/EC

RES-E Electricity from renewable energy sources

SMR Steam methane reforming

WTW Well-to-wheel

\section{HIGHLIGHTS}

- There is not a universally accepted definition for green hydrogen

- Several green characterisation initiatives are under development

- Guarantees of origin demonstrate to consumers that they are using green hydrogen

- Harmonisation of guarantees of origin would facilitate international trade

- Policies must be aligned with those of other energy carriers to avoid discrimination 
GRAPHICAL ABSTRACT

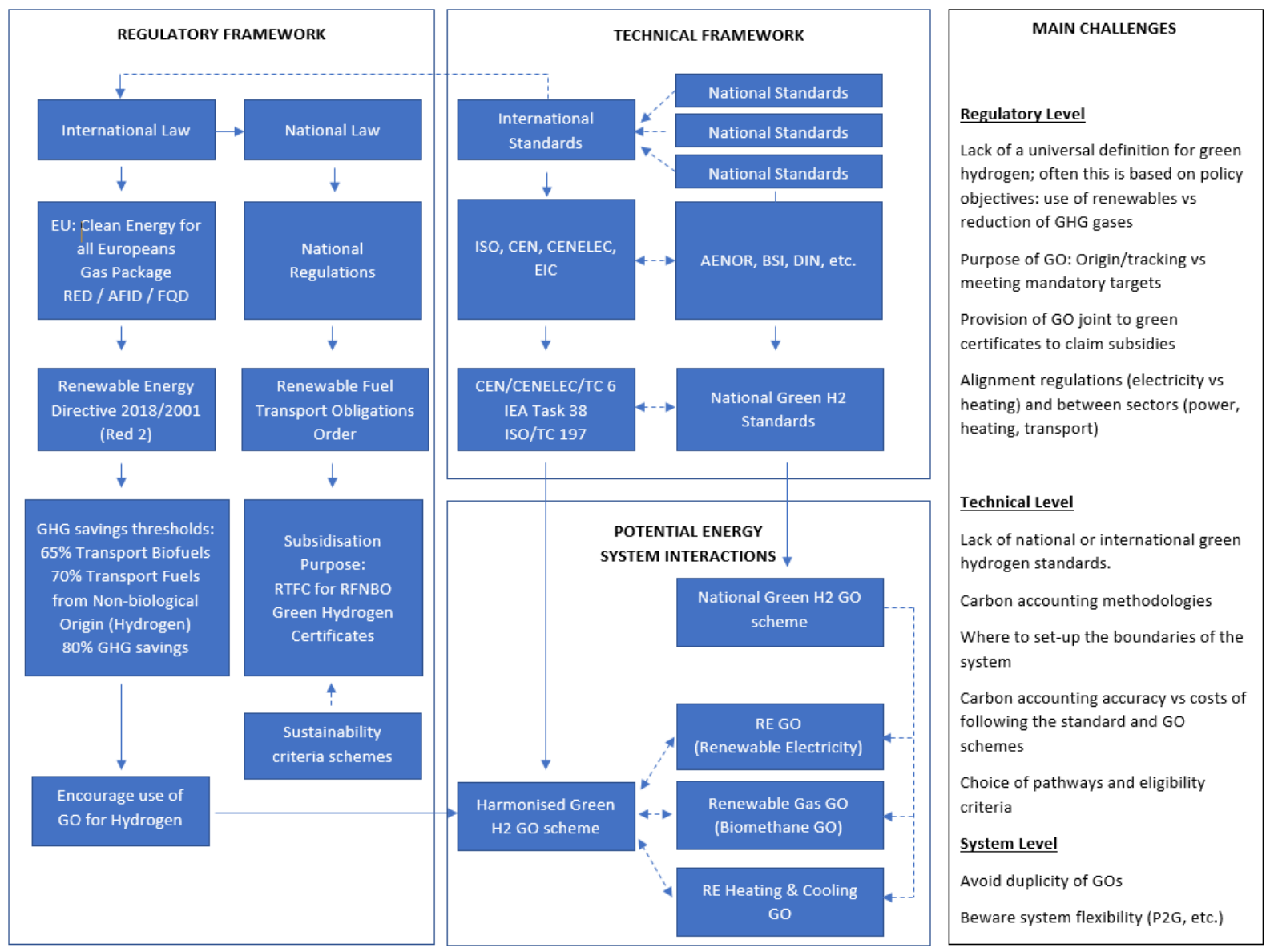




\section{INTRODUCTION}

Hydrogen is the only zero-carbon energy carrier other than electricity that is under serious consideration for low-carbon transport, industrial decarbonisation and heat provision in many countries ${ }^{1}$. Like electricity, hydrogen can be produced from different feedstocks (biological or not) and energy pathways (renewable or not). Renewable electricity benefits from subsidies or minimum purchase obligations in many countries, as it has in the past been more expensive than fossil fuel generation. These incentives require a standard to define renewable electricity. Low-carbon hydrogen is similarly more expensive than conventional hydrogen (BNEF, 2019), and if sustainable or renewable hydrogen is to be similarly supported by government climate policies in the future, then similar standards for hydrogen will be required.

Hydrogen that meets certain sustainability criteria has been termed "green" hydrogen, but there is no universally agreed definition yet as there is not an international green hydrogen standard. The first objective of this paper is to examine the various definitions of the "green" criteria that may be applied in future green or renewable hydrogen standards.

In contrast to renewable electricity, there is not yet a market for green hydrogen. While substantial quantities of hydrogen are currently used in industry, this is mostly produced from fossil fuels with high $\mathrm{CO}_{2}$ emissions (Velazquez Abad and Dodds, 2017). But hydrogen vehicles, heaters, and other appliances are now being commercialised, and this has underpinned several initiatives to develop green hydrogen standards. The second objective of this paper is to examine nascent national and supra-regional green hydrogen standards.

\footnotetext{
${ }^{1}$ Other commodities such as ammonia have also been proposed for long-distance international transport.
} 
National standardisation bodies (e.g. BSI, DIN, AENOR, etc.) both develop national standards and contribute to the work of supra-regional standardisation bodies (e.g. ISO, IEC). Often, this leads to alignment between national and international standards, which facilitates trade. Energy standards for the EU and the USA are developed by European Standardisation Organisations (e.g. CEN/CENELEC) and the American Standards Association Institute (ANSI), respectively, and are often linked to legislation (e.g. the Renewable Energy Directive in the EU and the Renewable Portfolio Standard in the USA). Standards are voluntary; however, legislation and regulations can refer to standards, making them compulsory. The energy industry has developed standards to create tradeable guarantees of origin (GOs) to provide security to consumers that they are consuming low-carbon or renewable energy. The third objective of this paper is to examine nascent guarantee of origin (GO) schemes for green hydrogen.

This paper is organised as follows. Section 2 compares the various definitions of green hydrogen that appear in the literature. Section 3 analyses green hydrogen standards and guarantees of origin that are being developed around the world. Section 4 assesses the main challenges to developing such initiatives. Section 5 considers policy barriers and suggests alternatives and Section 6 concludes questioning the suitability of implementing green hydrogen standards at the initial stages of market development.

\section{GREEN HYDROGEN DEFINITIONS}

The first reference we have found to the term green or renewable hydrogen was mentioned by NREL (1995), who used the term renewable hydrogen (hydrogen produced from renewables) as a synonym for green. The State of California (2006) defined green hydrogen as being produced cleanly and sustainably, using a renewable source such as solar or wind. 
The first mention of green hydrogen in EU policy documents is the declaration for establishing a green hydrogen economy in Europe (European Parliament, 2007).

Definitions of green hydrogen in the literature can be split into the seven categories listed in Table 1. There is not a harmonised definition, which in turn makes international trade, and the inclusion of hydrogen in energy policies, more difficult. In contrast, the definition for "black/brown" hydrogen is more homogeneous and it is typically understood as hydrogen produced from fossil fuels feedstocks (Bellaby et al., 2012; Clark, 2007; Public Citizen, 2003; Rifkin, 2002; State of California, 2006), with some sources also including nuclear power sources in this group (Clark, 2007; Public Citizen, 2003; Rifkin, 2002). Yet others categorise hydrogen from fossil, nuclear, and industrial residual gases as green, or 'clean' (e.g. Naterer et al. (2008)), or 'blue' (World Energy Council, 2019), when their GHG emissions are sufficiently low. ${ }^{2}$ Aarnes et al. (2018) exclude blue hydrogen when $\mathrm{CO}_{2}$ is used for enhancing oil recovery. Just 2 out of 7 of the categories in Table 1 focus on GHG emissions reductions (with or without supplementary environmental targets), and are truly technology-neutral (include any production pathway). The remaining categories state that green hydrogen requires the use of renewable pathways, with or without caveats.

The definition of renewable hydrogen is somewhat more universal, as it constraints the eligibility of pathways to renewables sources. Existing definitions can be used to define renewable sources, for example the EU Directive 2018/2001/EC (also known as RED 2) (European Commission, 2018). However, additional eligibility criteria (such as a carbon

\footnotetext{
${ }^{2}$ Emissions from fossil sources can be reduced by integrating carbon capture and storage technologies into hydrogen production processes.
} 
intensity threshold) can also differentiate (from a legal standpoint) the different interpretations adopted by governments and standardisation bodies.

\begin{tabular}{|c|c|}
\hline Definition & Sources \\
\hline Any renewable sources & $\begin{array}{l}\text { Poullikkas (2007); Clark II (2008); Clark II and } \\
\text { Rifkin (2006); Clark II et al. (2005); Clark (2007); } \\
\text { FCH-JU (2014); Kameyama et al. (2011); Kramer et } \\
\text { al. (2007); Ota et al. (2010); Public Citizen (2003); } \\
\text { Rifkin (2002); State of California (2006); Tada et } \\
\text { al. (2012); Weidong and Zhuoyong (2012) }\end{array}$ \\
\hline $\begin{array}{l}\text { Any renewable energy sources with } \\
\text { an explicit mention to air pollution, } \\
\text { energy security and global climate } \\
\text { problems }\end{array}$ & NREL (1995) \\
\hline $\begin{array}{l}\text { Any renewable energy sources with } \\
\text { an explicit mention to low emission } \\
\text { GHG intensity factors }\end{array}$ & $\begin{array}{l}\text { Bleischwitz and Bader (2008); CertifHy (2016); } \\
\text { Galich and Marz (2012); Gazey et al. (2012); } \\
\text { AFHYPAC (2016); CEP (2013); TÜV SÜD (2011b); } \\
\text { Viesi et al. (2017); Aarnes et al. (2018) }\end{array}$ \\
\hline $\begin{array}{l}\text { Any renewable sources or any other } \\
\text { net zero carbon energy through CCS } \\
\text { and/or emissions offsets. }\end{array}$ & Goverment of Australia et al. (2017) \\
\hline Any renewable and nuclear sources & Naterer et al. (2008) \\
\hline
\end{tabular}




\begin{tabular}{|l|l|}
\hline Any sources (renewable or not) & DECC (2015); Dincer (2012) \\
with an unspecified low emission & \\
intensity & \\
\hline Any low carbon energy sources with & Çelik and Yıldı (2017) \\
low environmental impact & \\
\hline
\end{tabular}

Table 1. Green hydrogen definitions in the literature. 


\begin{tabular}{|c|c|c|c|c|c|c|}
\hline $\begin{array}{l}\text { Body } \\
\text { (Country) }\end{array}$ & Type & Main Policy Objective & $\begin{array}{l}\text { Baseline GHG } \\
\text { threshold }\end{array}$ & Qualification level & Qualifying processes & $\begin{array}{l}\text { System } \\
\text { boundary }\end{array}$ \\
\hline $\begin{array}{l}\text { AFHYPAC }^{3} \\
\text { (France) }\end{array}$ & $\begin{array}{l}\text { GO scheme } \\
\text { (working } \\
\text { group } \\
\text { proposal) }\end{array}$ & $\begin{array}{l}\text { Renewable energy } \\
\text { source }\end{array}$ & None & Must be $100 \%$ renewable & $\begin{array}{l}\text { Any renewable pathway, } \\
\text { including electrolysis } \\
\text { powered by waste (with } \\
\text { renewable electricity or } \\
\text { biomethane GO). }\end{array}$ & $\begin{array}{l}\text { Point of } \\
\text { production }\end{array}$ \\
\hline $\begin{array}{l}\text { BEIS }^{4} \\
\text { (UK) }\end{array}$ & $\begin{array}{l}\text { Standard } \\
\text { Consultation } \\
\text { (abandoned) }\end{array}$ & $\begin{array}{l}\text { Reduction of } \mathrm{CO}_{2} \\
\text { emissions }\end{array}$ & Never determined & $\begin{array}{l}\text { To be determined. A single } \\
\text { threshold differentiated } \\
\text { according to end use (e.g. } \\
\text { transport) }\end{array}$ & Any (technology neutral) & $\begin{array}{l}\text { Point of } \\
\text { production }\end{array}$ \\
\hline $\begin{array}{l}\text { California Low } \\
\text { Carbon Fuel } \\
\text { Standard }\end{array}$ & $\begin{array}{l}\text { Regulation } \\
\text { (active) }\end{array}$ & $\begin{array}{l}\text { Reduction of air quality } \\
\text { and } \mathrm{CO}_{2} \text { emissions. Third } \\
\text { of vehicle hydrogen }\end{array}$ & $\begin{array}{l}\text { WTW emissions } \\
\text { from new gasoline } \\
\text { vehicles }\end{array}$ & $\begin{array}{l}30 \% \text { lower GHG and } 50 \% \\
\text { lower NOx emissions (on }\end{array}$ & $\begin{array}{l}\text { Renewable electrolysis, } \\
\text { catalytic cracking of SMR of } \\
\text { biomethane or }\end{array}$ & $\begin{array}{l}\text { Point of } \\
\text { use }\end{array}$ \\
\hline
\end{tabular}

${ }^{3}$ L'Association Française pour l'Hydrogène et les Piles à Combustible

${ }^{4}$ BEIS Green Hydrogen Standard was a consultation process that did not result in an official standard. 


\begin{tabular}{|c|c|c|c|c|c|c|}
\hline & & $\begin{array}{l}\text { produced from } \\
\text { renewable energy. }\end{array}$ & & $\begin{array}{l}\text { WTW per mile basis) for fuel } \\
\text { cell electric vehicles }\end{array}$ & $\begin{array}{l}\text { thermochemical conversion } \\
\text { of biomass, including MSW. }\end{array}$ & \\
\hline $\begin{array}{l}\text { CEN/CENELEC } \\
\text { CLS JCT } 6 \\
\text { WG1 / WG2 } \\
\text { (International) }\end{array}$ & $\begin{array}{l}\text { International } \\
\text { Standard } \\
\text { (in } \\
\text { preparation) }\end{array}$ & $\begin{array}{l}\text { Terminology, GO, } \\
\text { interfaces, operational } \\
\text { management, safety, } \\
\text { training and education }\end{array}$ & $\begin{array}{l}\text { Adopted from } \\
\text { CertifHy }\end{array}$ & Adopted from CertifHy & Adopted from CertifHy & $\begin{array}{l}\text { Adopted } \\
\text { from } \\
\text { CertifHy }\end{array}$ \\
\hline $\begin{array}{l}\text { CERTIFHY } \\
\text { (EU wide) }\end{array}$ & $\begin{array}{l}\text { GO scheme } \\
\text { (testing) }\end{array}$ & $\begin{array}{l}\text { Renewable energy } \\
\text { source / GHG emissions }\end{array}$ & $\begin{array}{l}\text { Hydrogen } \\
\text { produced via SMR } \\
\text { of natural gas }\end{array}$ & $\begin{array}{l}\text { At least } 60 \% \text { lower than } \\
\mathrm{SMR}^{5} \text { (this is } \leq 36.4 \\
\mathrm{gCO}_{2} \mathrm{e} / \mathrm{MJ} \mathrm{H} 2 \text { for the past } 12 \\
\text { months) }\end{array}$ & $\begin{array}{l}\text { Any renewable pathway } \\
\text { meeting the threshold with } \\
99.5 \% \text { purity }\end{array}$ & $\begin{array}{l}\text { Point of } \\
\text { production }\end{array}$ \\
\hline $\begin{array}{l}\text { TÜV SÜD } \\
\text { (Germany) }\end{array}$ & $\begin{array}{l}\text { National } \\
\text { Standard } \\
\text { (active) }\end{array}$ & $\begin{array}{l}\text { Reduction of } \mathrm{CO}_{2} \\
\text { emissions }\end{array}$ & $\begin{array}{l}\text { Hydrogen from } \\
\text { SMR of natural gas }\end{array}$ & $\begin{array}{l}35-75 \% \text { emissions reduction } \\
\text { below baseline (83.8-89.7 } \\
\text { gCO2e/MJ), depending on }\end{array}$ & $\begin{array}{l}\text { Renewable electrolysis; } \\
\text { biomethane SMR; pyro- } \\
\text { reforming of glycerine }\end{array}$ & $\begin{array}{l}\text { Point of } \\
\text { use }\end{array}$ \\
\hline
\end{tabular}

\footnotetext{
${ }^{5}$ The baseline carbon intensity considered by CertifHy for SMR is $91 \mathrm{gCO}_{2} \mathrm{e} / \mathrm{MJ} \mathrm{H}_{2}$
} 


\begin{tabular}{|l|l|l|l|l|l|l|}
\hline & & & & production process, and time & & \\
phase & & & \\
\hline
\end{tabular}

Table 2. Green hydrogen characterisation initiatives worldwide. 


\section{GREEN HYDROGEN CHARACTERISATION INITIATIVES}

Although there are several technical standards for hydrogen (e.g. ISO 14687 "Hydrogen Fuel Quality", ISO/TC 197 "Hydrogen Technologies"; IEC TC/105 "Fuel Cells"; CEN/CLC/SFEM/WG "Hydrogen" (CEN/CENELEC, 2019)), the lack of a formal standard for green hydrogen reflects the disparity of interpretations found in the literature. The main green hydrogen characterisation initiatives found worldwide are described in Table 2, and include the preliminary work undertaken by standardisation agencies (e.g. CEN CLC JTC 6), certification bodies (e.g. TÜV SÜD), and the outcome of projects and consultation processes in the area of energy and climate policy (e.g. EU CertifHy, AFHYPAC, and the governments of California and the UK).

\subsection{Green hydrogen standards}

CEN/CENELEC (2018) defines a standard as a document that provides rules, guidelines or characteristics for activities or their results. Figure 1 briefly illustrates the process for creating a new standard based on ISO (2019). The ISO publishes a proposal from a group of external experts or organisations. The feedback is fed into a technical specification, with input from technical committees (TC) including technical experts from the industry, consumers' associations, academia, NGOs and government. The draft standard becomes an ISO International Standard following approval from the ISO secretariat. 


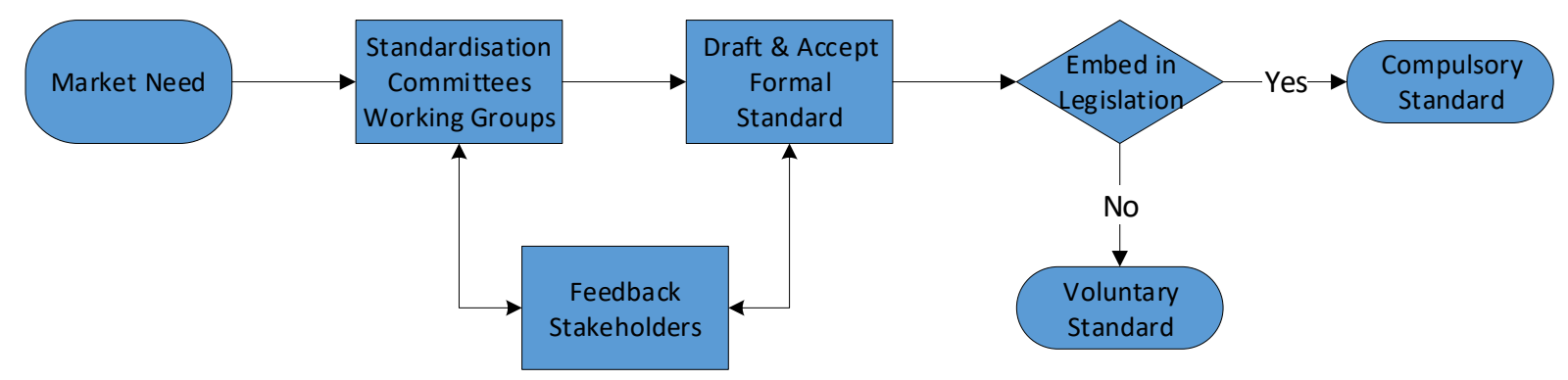

Figure 1. Process flow creation and implementation of a formal standard.

\subsubsection{European CEN/CENELEC/TC 6 standard}

The scope of the CEN/CENELEC/TC 6 standards under development includes terminology, Guarantee of Origin, and safety, with the possibility of adding other cross-cutting issues such as societal aspects and operational conditions in the future (CEN, 2016). CEN/CENELEC/TC 6 will adopt the "CertifHy Green Hydrogen" terminology, definitions, and GO system (Section 3.2.3). One challenge for this standard is to make it complement other CEN/CENELEC hydrogen standards that are in parallel development.

\subsubsection{TÜV SÜD standard}

TÜV SÜD Standard CMS 70 is a German standard that defines green hydrogen as 'hydrogen, from renewable energy sources and/or waste' (TÜV SÜD, 2011b). This standard defines requirements and rules for feedstocks, eligibility of production processes, GHG savings and delivery conditions (e.g. output pressure; purity; technologies). The baselines against which emission intensities are compared, and the percentage of GHG savings required for certifying green hydrogen, varies according to the method of production (process) and the intended end use, as shown in Table 3 . The counterfactual for hydrogen used in transport is a petroleum fuel. Conventional hydrogen, produced via steam methane reforming, is the counterfactual for other end uses. Three types of green hydrogen production processes 
qualify under this standard: (i) electrolysis of water using renewable electricity; (ii) steam reforming of biomethane; and, (iii) pyro-reforming of glycerine (when this is a by-product of production of biodiesel). The renewable electricity of the electrolytic hydrogen has to be certified by one of four quality labels: TÜV-Nord/TÜV-South Green Electricity, Green Power Label or OK Power.

The 'system boundary' for calculating GHG emissions covers the whole supply chain from production of feedstocks up to the delivery of the hydrogen to the filling station (at $20 \mathrm{MPa}$ ), or, for stationary applications, to the end customer (delivered at $3 \mathrm{MPa}$ ). Embedded GHG emissions from capital investments, waste streams and end-of-life are not counted. The renewable origin of feedstocks can be demonstrated through the pre-existing certification schemes under which these products fall - the 'biogas register' when biomethane is used for producing the hydrogen; an equivalent certification scheme for glycerine; and the renewable energy GO (RES-E GO) scheme for electricity (TÜV SÜD, 2011b). Additional qualifying criteria are related to the age of the production plant and whether it received any subsidies for renewable energy generation in the past. 


\begin{tabular}{|l|l|c|c|}
\hline \multicolumn{1}{|c|}{ Production process } & End Use & Baseline & Minimum emissions \\
& & (gCO ${ }_{2}$ e/MJ) & reduction level to be \\
“green"
\end{tabular}

Table 3. Requirements for the TÜV SÜD Green Hydrogen certification, according to the production process and end use. Adapted from: TÜV SÜD (2011b).

\subsubsection{BEIS consultation}

The UK Department of Business, Energy and Industrial Strategy ${ }^{6}$ (BEIS) set up a working group in 2014 to develop a green hydrogen standard for the UK. From the outset, two overriding principles were: (i) that the standard would have separate categories for low-carbon and renewable-derived hydrogen; and, (ii) that the GOs certificates would be tradeable. BEIS carried out a public consultation about a prospective standard in 2015. The principal questions and their consultation outcomes are summarised in Table 4. The consultation concluded that including air quality emissions would complicate the delivery of the standard and it also considered that these were well covered by other regulations (e.g. air quality laws). The choice of a single $\mathrm{CO}_{2}$ threshold instead of separated ones (according to the end use of hydrogen), is aligned with the idea of technology neutrality, and it was expected that this limit

\footnotetext{
${ }^{6}$ BEIS includes the former UK Department for Energy and Climate Change (DECC).
} 
would be reviewed over time in light of future UK carbon budgets. The main differences with TÜV SÜD were the eligibility criteria of the pathways and the boundaries of the system (Table 2). The process to develop a standard was suspended indefinitely in 2017 due to the lack of an existing market.

\begin{tabular}{ll}
\hline Issue & Decision \\
\hline Economic sectors & All energy sectors using hydrogen \\
\hline Definition of green hydrogen & All pathways (including non-renewable) that \\
& met a GHG emission intensity threshold
\end{tabular}

Determination of emission intensity

Single GHG threshold for all end-uses thresholds

\begin{tabular}{|c|c|}
\hline System boundaries & Point-of-production \\
\hline Inclusion of additional sustainability criteria & No \\
\hline Whether a UK standard would be redundant & The UK emphasis on technology neutrality is \\
\hline if there were a harmonised EU standard & different to other standardisation initiatives \\
\hline
\end{tabular}

Table 4. Principal green hydrogen standard issues identified BEIS in a public inquiry, and the decisions reached (DECC, 2015).

\subsection{Guarantees of origin}

The European Standard EN16235:2013+A1:2015 defines GOs as certificates issued under a national GOs scheme with the purpose of disclosure and supporting labelling (BSI, 2015). GOs are tracking mechanisms, while green certificates are documents used as proof of eligibility for support schemes (European Commission, 2018). 
There is legal obligation for electricity suppliers to provide disclosure details to their end customers. GOs are used to demonstrate that their energy comes from a specific source of production. GOs can be traded and recognised cross-border within the EU. The RED 2 defines GOs for energy from renewable sources as an electronic document, issued by an EU member state (or its competent body), whose purpose is to demonstrate "to final customers the share or quantity of energy from renewable sources in an energy supplier's energy mix and in the energy supplied to consumers" under green tariffs (European Commission, 2018). In the USA, the equivalent GOs are called renewable energy certificates or credits, and are market-based instruments that represent the ownership of the environmental, social and other non-energy attributes of renewable electricity generation (US EPA, 2018).

The RED 2 recommends the extension of the renewable electricity (RE) GO scheme to cover renewable gases (e.g. green hydrogen; biomethane), but also to low-carbon, non-renewable sources. Most of the characteristics that apply to RE GO also apply to green hydrogen and biomethane GO; however, due to the physical characteristics of electricity (electrons) versus gases (molecules) the way of tracking origins differs. This is known as the "chain of custody" (European Commission, 2010) and there are three main approaches: segregation, mass balance, and book and claim (Mol and Oosterveer, 2015), as illustrated in Figure 2. The segregation approach requires the commodity to be tracked at each stage of the supply chain, with all buyers and sellers connected in the same grid/network, and separating certified commodities from conventional ones. A segregated approach could be applied when green hydrogen can be physically tracked at each stage of the supply chain and it is not mixed with non-green hydrogen. The mass balance approach similarly has a physical link between all stages of the supply chain (Staaij et al., 2012), but buyers and sellers do not need to be connected into the same grid/network, and certified and non-certified commodities can be 
mixed if each are tracked. The mass balance approach would allow the injection of green hydrogen into gas grids, together with non-green hydrogen and natural gas, as long as the volume of certified green hydrogen entering the network were equivalent to the volume exiting it. The book and claim approach decouples the physical flow of the commodity and the trade of its GO, enabling both to be commercialised independently. In all cases, producers and buyers must be physically connected to enable the flow of energy. Renewable electricity GOs can only operate in a book and claim approach, as it is not possible to ensure that a particular batch of electricity correspond to a particular source, as electrons cannot be tracked back to their origin once they are fed into the grid. Under a book and claim, green hydrogen molecules and GO would be sold separately, and there would be no need for physical traceability.

(a) Segregated

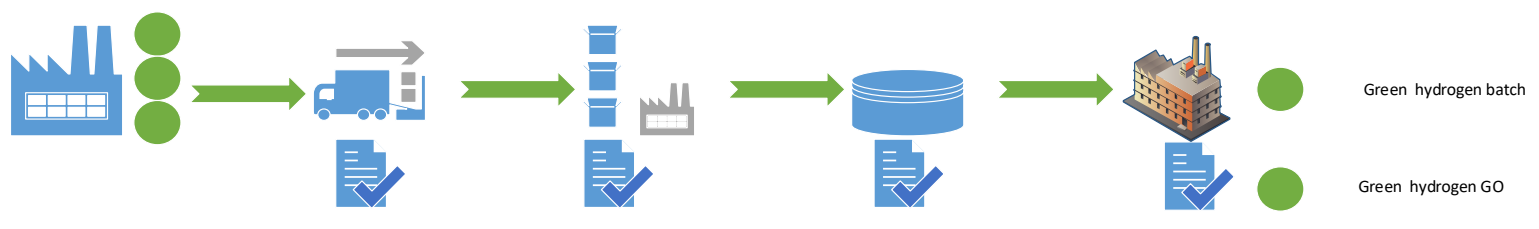

(b) Mass balance

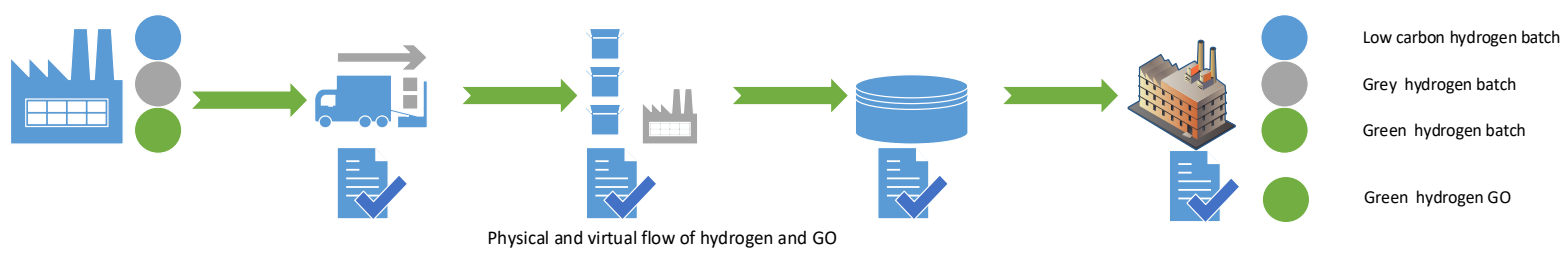


(c) Book and claim

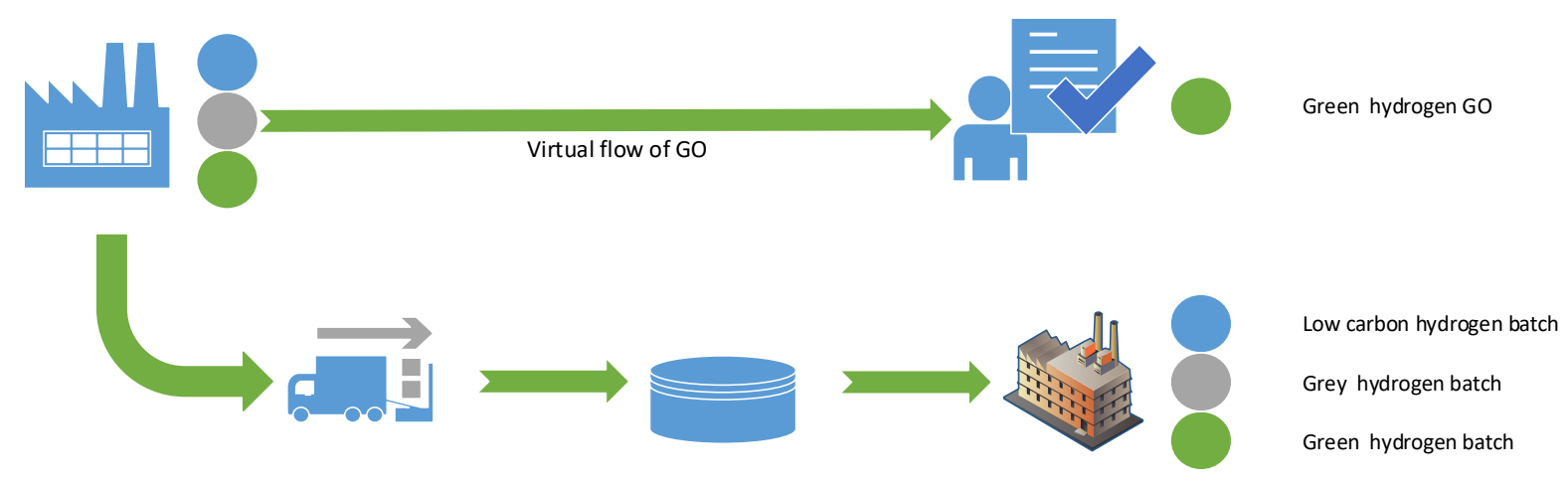

Physical flow of hydrogen

Figure 2. Chain of custody approaches for green hydrogen guarantees of origin.

The system for managing and trading GOs in Europe is illustrated in Figure 3 and follows a book and claim approach, as it is based on the renewable electricity chain of custody (AIB, 2017). A hydrogen GO scheme could follow this or could use a mass-balance approach, like other biomethane GO schemes. As described by the AIB (2017), each EU country is responsible for managing $\mathrm{GO}$ trading and they delegate this function to national registries, who are the competent authorities. Energy producers must be accredited by an auditor, who ensures that the production plant meets the eligibility criteria set up in the standard, prior to their participation in the GOs market. An issuing body issues a GO to eligible producers for each MWh of energy that they produce, and, via a clearing system operated via a trading platform, they ensure that when a customer buys the GO this ownership is transferred. Customers can claim the GO when they offer green hydrogen tariffs to consumers, at which point the issuing body cancels the GO. If the GO is not sold or claimed within a given period, it expires or is auctioned on behalf of the government. The list of attributes that must appear in each GO are specified in the RED 2 (Table 5) and establish the minimum details for any EU green hydrogen GO scheme compliant with EU law. 
EU Renewable Energy Directive 2018/2001 - Relevant ISO / CEN-CENELEC Green Hydrogen and GO Standards

Main Regulatory Framework

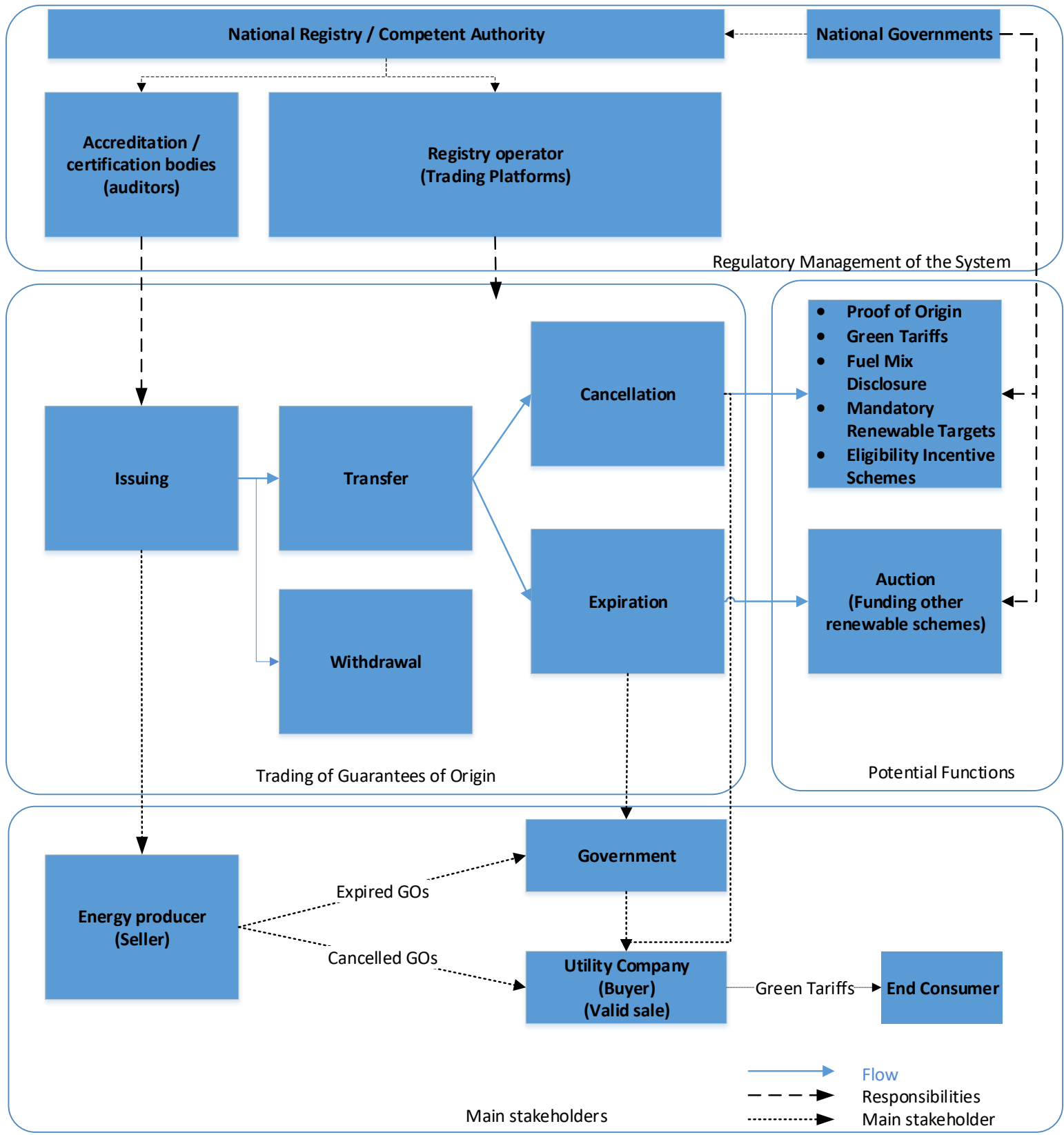

Figure 3. Management and trading of guarantees of origin in Europe.

\subsubsection{Renewable electricity and biomethane GO schemes}

The European Energy Certificate System (EECS) framework harmonises the creation, maintenance, transfer, cancellation and other processing of EECS certificates, with the aim of 
encouraging trade in GOs certificates between member states (BSI, 2015). The EECS is developed, used and promoted by the Association of Issuing Bodies (AIB, 2017). Member States national GOs registries issue green electricity GOs to eligible generators (based on selfreported submissions, with periodic audits), and deal with transfer, cancelation, clearing and delivery of GOs (as shown in Figure 3). The EECS supports EU Renewable Energy Certificates (RECS), Guarantees of Origin for renewable electricity (RES-E GO), Guarantees of Origin for electricity from cogeneration (RES-E CHP GO) and generic guarantees of origin, all handled in one coherent certificate system. Yet some EU countries are not members of the Association of Issuing Bodies and do not follow EECS rules. The inclusion of additional independent sustainability criteria also varies between countries and they may be used to enhance the environmental attributes associated with their energy consumption; however, it is not required to attach these to any $\mathrm{GO}$.

\begin{tabular}{|c|c|c|c|}
\hline \multirow{7}{*}{ 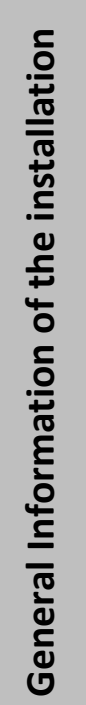 } & \multirow{7}{*}{ 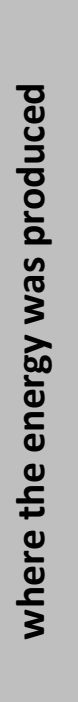 } & \multirow{7}{*}{ 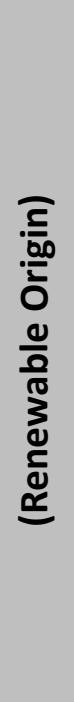 } & Unique identification number \\
\hline & & & Identity \\
\hline & & & Location \\
\hline & & & Type of installation \\
\hline & & & Capacity of the installation where the energy was produced \\
\hline & & & Start-up date (when the facility became operational) \\
\hline & & & Kind and amount of investment support \\
\hline \multirow{3}{*}{ 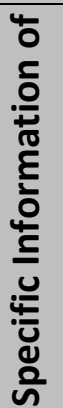 } & \multirow{3}{*}{ 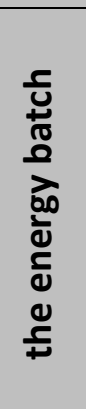 } & \multirow{3}{*}{ 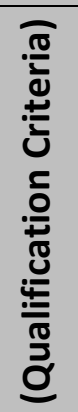 } & The energy source from which the energy was produced \\
\hline & & & Date of production (start/end energy of production) \\
\hline & & & $\begin{array}{l}\text { Specify whether the GO relates to electricity, gas (including hydrogen) or } \\
\text { heating and cooling }\end{array}$ \\
\hline
\end{tabular}




\begin{tabular}{|l|l|}
\hline & Country of issue \\
\cline { 2 - 2 } & Benefits of the unit of energy from a national support scheme and type \\
\hline
\end{tabular}

Table 5. Minimal specifications to include in a GO in Europe. Adapted from: European Commission (2018).

Biomethane GOs exist because EU legislation enables economic operators to use recognised voluntary schemes or bilateral and multilateral agreements to show compliance with certain sustainability criteria (European Commission, 2010). They are used by gas utility companies for commercialising renewable biogas or biomethane tariffs and, in some countries, are required as a proof of origin when claiming renewable incentives. There is no harmonised biogas/biomethane GO scheme across the EU, and even definitions vary between schemes. For example, German and Swiss GO schemes consider biomethane and biogas to be interchangeable, while Italian and French schemes distinguish biomethane as an upgraded biogas with higher purity. The main differences between biomethane/biogas GO schemes that operate in European countries appear in Table 6. Any of these could constitute the basis for a green hydrogen GO. Harmonisation efforts across Europe are being pursued through the European Renewable Gas Registry (ERGaR), but only for gas transported by pipeline (ERGaR, 2017). 


\begin{tabular}{|c|c|c|c|c|c|c|c|}
\hline $\begin{array}{l}\text { Cou } \\
\text { ntry }\end{array}$ & Name & Management Body & $\begin{array}{l}\text { ISC } \\
\text { (label) }\end{array}$ & $\begin{array}{l}\text { Compatible with } \\
\text { other schemes }\end{array}$ & Unit & $\begin{array}{l}\text { Supply Chain } \\
\text { Custody } \\
\text { System }\end{array}$ & Sources \\
\hline $\mathrm{CH}$ & $\begin{array}{l}\text { Garanties d'origine } \\
\text { pour le biogaz }\end{array}$ & $\begin{array}{l}\text { I'Association Suisse } \\
\text { de I'Industrie Gazière } \\
\text { (ASIG)/ VSG }\end{array}$ & Naturemade & Yes & $1 \mathrm{kWh}$ & $\begin{array}{l}\text { Mass balancing } \\
\text { system }\end{array}$ & $\begin{array}{l}\text { ASIG (2016); OFEN } \\
\text { (2015); VUE (2016) }\end{array}$ \\
\hline $\mathrm{DE}$ & $\begin{array}{l}\text { Biogasregister } \\
\text { Deutschland7 }\end{array}$ & $\begin{array}{l}\text { Deutsche } \\
\text { Energieagentur } \\
\text { (DENA) }\end{array}$ & $\begin{array}{l}\text { REDcert EU } \\
\text { ISSC EU }\end{array}$ & $\begin{array}{l}\text { Yes (EEG, } \\
\text { EEWärmeG, } \\
\text { BioKraftNachV) }\end{array}$ & $1 \mathrm{kWh}$ & $\begin{array}{l}\text { Mass balancing } \\
\text { system }\end{array}$ & $\begin{array}{l}\text { DENA (2017); TÜV SÜD } \\
\text { (2011c, 2012, 2014); } \\
\text { Veum et al. (2016) }\end{array}$ \\
\hline FR & $\begin{array}{l}\text { Registre des } \\
\text { Garanties d'Origine } \\
\text { Biomethane } \\
\text { (RGOB) }\end{array}$ & $\begin{array}{l}\text { Gaz Réseau } \\
\text { Distribution France }\end{array}$ & $N / A$ & Yes & $1 \mathrm{MWh}$ & Book \& Claim & $\begin{array}{ll}\text { ADEME } & (2015) ; \\
\text { AFHYPAC } & (2014 \mathrm{~b}) ; \\
\text { Legifrance } & (2017) ; \\
\text { Veum et al. (2016) }\end{array}$ \\
\hline
\end{tabular}

\footnotetext{
${ }^{7}$ Certified as Green Methane by TÜV SÜD.
} 


\begin{tabular}{|c|c|c|c|c|c|c|c|}
\hline IT & $\begin{array}{l}\text { Garanzia di Origine } \\
\text { di Biometano }\end{array}$ & $\begin{array}{l}\text { Gestore Servizi } \\
\text { Elettrici (GSE) }\end{array}$ & Energia Verde & No & $1 \mathrm{MWh}$ & $\mathrm{N} / \mathrm{A}$ & $\begin{array}{l}\text { AEEGSI (2015); GSE } \\
\text { (2016) } \\
\text { Ministry of Economic } \\
\text { Development (2016) }\end{array}$ \\
\hline UK & $\begin{array}{l}\text { Renewable Gas } \\
\text { Guarantee of Origin } \\
\text { (RGGO) }\end{array}$ & $\begin{array}{l}\text { Green Gas } \\
\text { Certification Scheme } \\
\text { (REA) }\end{array}$ & $\begin{array}{l}\text { Biomethane } \\
\text { Certification } \\
\text { Scheme (BCS) }\end{array}$ & Yes (RHI) & $1 \mathrm{kWh}$ & $\begin{array}{l}\text { Book and } \\
\text { claim }\end{array}$ & $\begin{array}{ll}\text { GGCS } \quad(2016) ; \quad \text { GGT } \\
(2016) & \end{array}$ \\
\hline
\end{tabular}

Table 6. Biomethane guarantees of origin schemes in several European countries. CH: Switzerland; DE: Germany; FR: France; IT: Italy; UK: United Kingdom. 


\subsubsection{Green Hydrogen GO Scheme - AFHYPAC}

L'Association Française pour l'Hydrogène et les Piles à Combustible (AFHYPAC) has proposed a GO scheme for renewable hydrogen for France that mirrors, and would enable interactions with, existing French electricity and biomethane scheme (AFHYPAC, 2014b, 2016). It requires green hydrogen to be produced from renewables and to meet a GHG emissions threshold, similar to the TÜV SÜD Standard CMS 70, but restricts carbon accounting boundaries at the point of production rather than at the point of use (Table 2). Each GO corresponds to $1 \mathrm{MWh}$ of renewable hydrogen and would have a validity of 2 years from its date of origin (AFHYPAC, 2014a). This diverges from the 12 months proposed by CertifHy, so would prevent the trade of GOs between schemes.

More recently, there has been a shift in French hydrogen policy from renewable to zero carbon hydrogen ('hydrogène décarboné'), which includes hydrogen produced from fossil fuels with CCS, in a similar approach to BEIS. Although this AFHYPAC proposal has not been implemented, the French government expects to have a GO tracking system in place for zerocarbon hydrogen produced from renewables by 2020 that will support a goal for industry of $10 \%$ of green hydrogen by 2023, and up to $40 \%$ by 2028 (Ministère de la Transition écologique et solidaire, 2018).

\subsubsection{Green Hydrogen GO Scheme - CertifHy}

CertifHy is developing a framework for an EU-wide GO scheme for hydrogen (Wabitsch and Vanhoudt, 2016). In contrast to TÜV SÜD and CEN/CENELEC, the primary focus of CertifHy has been the GO system rather than the definition of a green hydrogen standard, and it is in practice a labelling scheme and a tracking mechanism. The labelling of hydrogen under the CertifHy GO scheme proposal is summarised in Figure 4. Hydrogen can be labelled as "Green 
hydrogen" when it produced from renewables following the sustainability criteria defined in the RED 2 (CertifHy, 2019). Initially, each MWh of green hydrogen had to meet a GHG emissions threshold of $36.4 \mathrm{gCO}_{2} \mathrm{e} / \mathrm{MJ}_{\mathrm{H} 2}$ on a well-to-tank basis to be certified, which represented a reduction of $60 \%$ compared to hydrogen produced using steam-methane reforming. This will be revised based on the 70\% target of RED 2 (European Commission, 2018) to $24.5 \mathrm{gCO}_{2} \mathrm{e} / \mathrm{MJ}_{\mathrm{H} 2}$ (CertifHy, 2019). Hydrogen from non-renewable sources that meets this limit is labelled 'low carbon hydrogen', and hydrogen between this limit and $91 \mathrm{gCO}_{2} \mathrm{e} / \mathrm{MJ}_{\mathrm{H} 2}$ is labelled as grey hydrogen (Castro et al., 2016).

Emissions are calculated at the point of production, using a similar approach to the BEIS or AFHYPAC suggestions (well-to-gate) and exclude capital goods, and downstream emissions (transport, supply, handling, consumption and end-of-life) (CertifHy, 2019). Emissions at the point of production (gate) assume a hydrogen purity of $99.9 \%$ vol at $3 \mathrm{MPa}$. The CertifHy scheme takes a similar technology-neutral approach to BEIS (CertifHy, 2018). Each GO represents $1 \mathrm{MWh}$ of green, grey or renewable hydrogen, and hydrogen from different sources can be mixed. CertifHy uses a book and claim approach to the chain of custody because it is thought to reduce management costs and be simpler to implement than the segregated or mass balance approaches. 


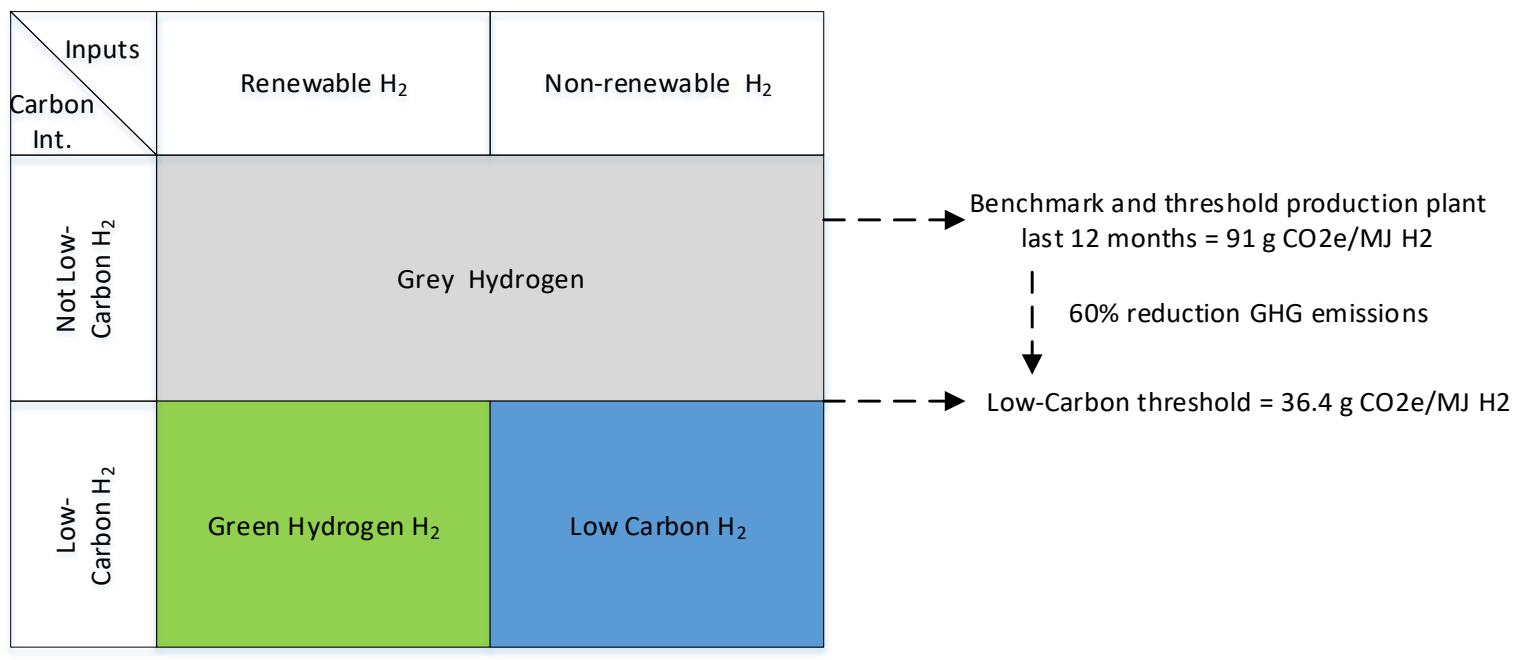

Figure 4. Categorisation of hydrogen according to the origin of its energy input and emission intensity. Adapted from Castro et al. (2016).

\subsection{Other policy initiatives relevant to green hydrogen}

\subsubsection{Asia}

The Korean government has published a hydrogen strategy and roadmap (Moon Jae-in, 2019). The national industry has also suggested a hydrogen roadmap where green hydrogen is defined as produced from renewables via electrolysis or via SMR with CCS (Study Task Force, 2018). This roadmap proposes incentive schemes by 2020 that include the extension of the Renewable Portfolio Standards (RPS) and the Renewable energy certificates (REC) scheme, to promote green hydrogen and hydrogen fuel cells. The RPS is a system that requires energy producers to supply a share of power from new and renewable energy by installing renewable energy power plants or procuring renewable energy certificates.

Japan's Basic Hydrogen Strategy envisages zero-carbon hydrogen being used in large quantities from 2030 in sectors that are difficult to decarbonise (e.g. industry; power generation; mobility) (METI, 2019). While it is required to develop renewable pathways, CCS is seen as critical to materialise the hydrogen economy at the pace that the country wants 
and until renewable hydrogen becomes cost-competitive. The Strategic Roadmap has set economic and efficiency targets for the supply of green hydrogen to be met by 2030 (cost and durability of electrolysers, and efficiency of electrolysis). Japan is not developing a green hydrogen standard or GO scheme; however, it follows developments in this area worldwide and it contributes to the work undertaken by international agencies (e.g. EIA, IPHE, Hydrogen Council) and ISO standards (METI, 2019).

\subsubsection{Australia}

Australia is developing an export-focused national hydrogen strategy (COAG, 2019). Some recommendations involve regulatory changes and the development of technical standards (e.g. initially allowing up to $10 \%$ hydrogen in the domestic gas network, and potentially up to $100 \%)$, and a labelling system, to materialise business opportunities as fast as possible. The Australian Renewable Agency (ARENA) has funded its first green innovation hub that will develop standards for green hydrogen production, distribution and use (ARENA, 2018). Green hydrogen is understood as hydrogen produced via electrolysis from renewable electricity, while clean hydrogen includes hydrogen produced from fossil fuels with the emissions captured and sequestered.

\subsubsection{European Union}

The EU RED 2 expands GOs to hydrogen, but it does not necessarily need to meet a green standard (European Commission, 2018). The Fuel Quality Directive and the RED 2 regulate the sustainability of biofuels. EU policy requires a $6 \%$ reduction of the GHG intensity of transport fuels by 2020. This only applies to petrol, diesel and biofuels used in road transport and gasoil used in non-road mobile machinery. Hydrogen produced from renewables is considered a renewable fuel of non-biological origin and as such can contribute to achieve this goal 
(European Commission, 2019). Green hydrogen can contribute to decreasing the carbon intensity of fossil fuels when used in refining processes such as in the desulphurisation of diesel. However, beyond 2020, the EU Commission has proposed to address transport fuel decarbonisation targets within the framework of the RED 2 (Article 25) by setting an obligation on fuel suppliers, rather than not member states, to ensure that by 2030 at least $14 \%$ of energy within the final consumption of energy in the transport sector is renewable (European Commission, 2018).

The Directive 2014/94/EC on Alternative Fuel Infrastructure identifies hydrogen as one of the alternative fuels with potential for long-term oil substitution (European Commission, 2014). This Directive promotes the construction of hydrogen refuelling networks, and it sets up voluntary targets for refuelling points to be deployed by December 2025. The Directive includes technical specifications for hydrogen refuelling points for motor vehicles; however, it enforces neither deployment targets nor the dispensing of green hydrogen within these refuelling points.

The EC has announced its intention to prepare a third "Gas Package" to take advantage of new opportunities such as renewable and decarbonised gases (e.g. green and blue hydrogen) (ENTSOG, 2018). It will likely enable mixing of green hydrogen in gas networks.

\subsubsection{USA}

The California Air Resources Board (CARB) is the governing body for California Senate Bill 1505 (SB 1505). This bill is significant to the Low Carbon Fuel Standard (LCFS) because it ensures that hydrogen produced at state-funded hydrogen refueling stations has lower carbon intensity than gasoline and it ensures that one third of the hydrogen dispensed is made from eligible renewable resources (CARB, 2019). The LCFS is a market-based mechanism that 
requires a reduction GHG intensity of transport fuels (petrol and diesel) with a trading system of credits and deficits based on the carbon intensity of the alternative fuels. This system has some similarities with the UK's Renewable Transport Fuel Obligation and the goal of Renewable Transport Fuel Certificates. Recent amendments in the LCFS have included renewable hydrogen. CARB (2018) defines renewable hydrogen as "derived from (i) electrolysis of water or aqueous solutions using renewable electricity; (ii) catalytic cracking or steam methane reforming of biomethane; or, (iii) thermochemical conversion of biomass, including the organic portion of municipal solid waste (MSW)". The carbon intensity for compressed $\mathrm{H}_{2}$ from on-site reforming with renewable feedstocks is $76.1 \mathrm{gCO}_{2} \mathrm{e} / \mathrm{MJ}$, which is considerably above CertifHy's threshold, even after including downstream emissions. These differences in carbon thresholds and carbon accounting methodologies would prevent GOs' trading between the USA and the EU.

\section{CHALLENGES IN THE CHARACTERISATION OF GREEN HYDROGEN}

\subsection{GHG emission accounting}

GHG emissions can occur at all stages along the hydrogen supply chain. Yet accounting for losses and emissions from distribution and storage of hydrogen is challenging, as there are several potential distribution routes, and emissions depend strongly on the supply and demand locations. Furthermore, complexity rises when considering the impact of end-uses (e.g. driving cycles in transport modes) and technological efficiency (e.g. turbines, internal combustion engines, and fuel cells). The use of default values can mitigate some of these hurdles; however, assumptions cannot be generalised to the same extent that is done with fossil fuels. 


\subsubsection{Emission accounting boundaries}

The system boundaries of different green hydrogen characterisation initiatives are illustrated in Figure 5. None of the schemes include emissions involved in constructing and decommissioning hydrogen production plants and other capital infrastructure, but emissions occurring from the transport of feedstocks up to the production plant are considered. Standards following the RED 2 methodology for transport fuels, biofuels and bioliquids include emissions from cultivating and extracting raw materials, annualised land use changes, processing, transport and distribution, fuel use, as well as GHG savings from soil carbon accumulation or carbon capture, storage and replacement (European Commission, 2018). Hydrogen transported as a cryogenic liquid should also include energy conversion to electricity and/or heat and cooling. GHG emissions at the "point of production" depend on: (i) the feedstock and any land use changes; (ii) energy inputs (e.g. the electricity emission intensity); (iii) the efficiency of the selected production technologies; and, (iv) any additional processes (e.g. compression, liquefaction) to bring the product to specification. GHG emissions at the "point of use" additionally include downstream emissions from storage (filling tanks or reservoirs), transportation (trucks, trains, ships or pipelines), handling and supply (e.g. compressing hydrogen at refuelling stations), and fuel losses due to boil-offs and leakages. Well-to-wheel emissions relate to transport modes and include emissions from the extraction and production of feedstocks up to end-use emissions (e.g. transport) but the same concept applies to other non-transport supply chains (e.g. heating; industrial processes). Cradle-to-grave is similar but also includes end-of-life emissions (disposal, reuse, recycling) of all technologies. 


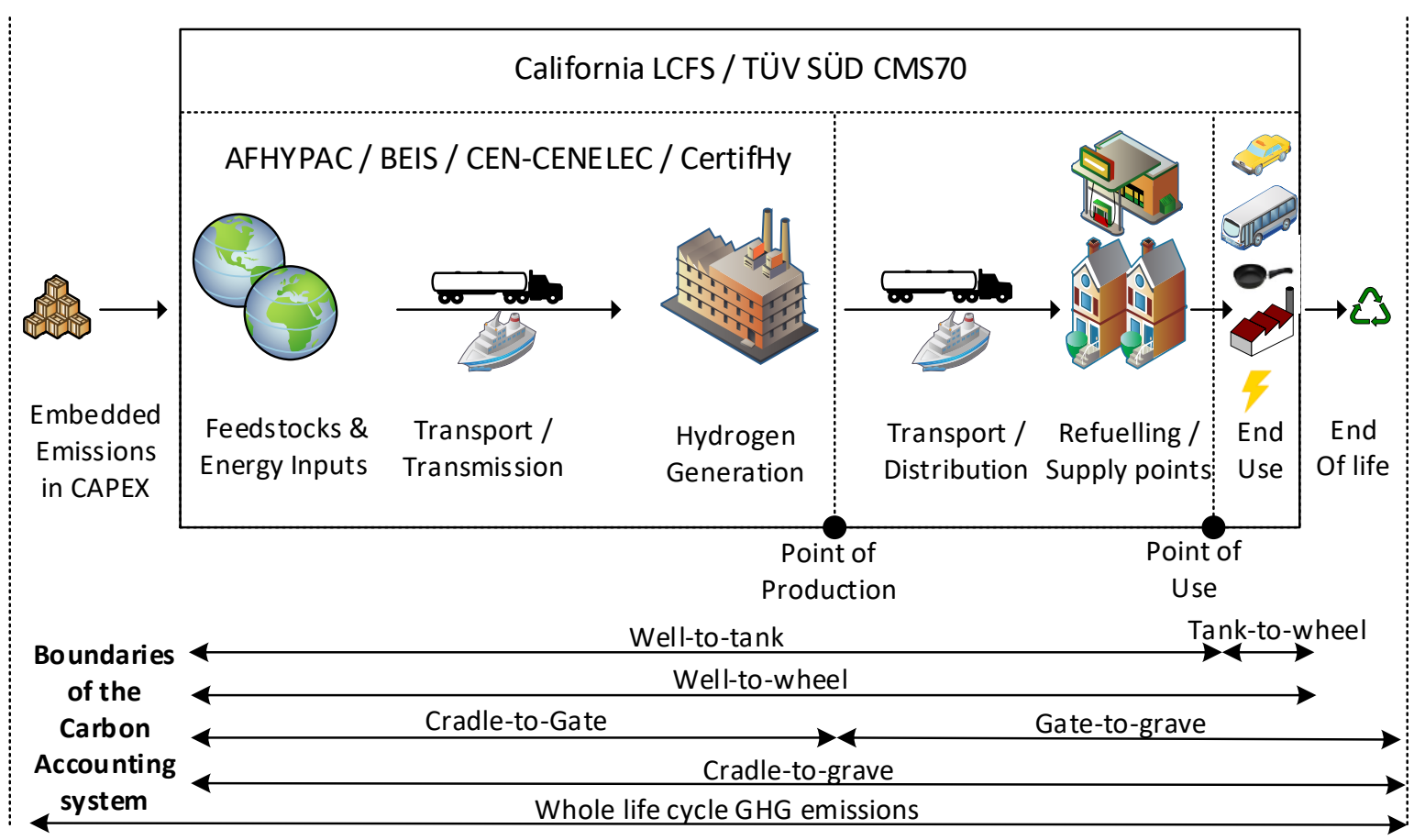

Figure 5. Carbon accounting system boundaries for different green hydrogen characterisation initiatives.

\subsubsection{Carbon accounting choices and trade-offs between accuracy and costs}

As reported by IEA Hydrogen Task 36, hydrogen LCA studies have multiple methodological inconsistencies (Valente et al., 2017). They vary, for example, in the definition of the hydrogen purity and compression specifications. The TÜV SÜD standard assumes a purity of $99.9999 \%$ and delivery as a $20 \mathrm{MPa}$ gas to refuelling stations (for transport), or at $3 \mathrm{MPa}$ in stationary applications (TÜV SÜD, 2011b). In contrast, CertifHy assumes 99\% purity and 3 MPa delivery. None of the standards in Section 3 consider liquefied hydrogen. Another variation between schemes is the use of different global warming potential factors, as these are updated by the IPCC in each assessment report and accepted as official values by the laws of each region; hence standards and GO schemes must be updated and harmonised accordingly. This means that the same hydrogen supply chain has different carbon intensities under different carbon accounting standards and conditions. A green hydrogen standard should state the GHGs 
assessed, their global warming potential and the carbon accounting methodology (Table 7). By aligning a green hydrogen GOs scheme with a standard, such issues would be raised and could be resolved at the outset.

The trade-off between accuracy and cost when estimating GHG emissions is a key decision for a green hydrogen standard and GOs scheme. For example, RED 2 provides the minimum necessary details of a renewable energy GO, on which initiatives such as CertifHy Green Hydrogen GO have also added the carbon intensity (CertifHy, 2019). RE GOs do not consider carbon intensity explicitly (European Commission, 2018) and this makes it less costly than the CertifHy proposed scheme. However, Directive 2018/2011 allows the use of default values for GHG emissions savings for the production pathways (European Commission, 2018), which reduces calculation costs but diminishes the accuracy of the values when compared to actual values (another of the methods allowed in the Directive). Calculating emissions at the "point of production" should be cheaper than tracking the GO downstream the supply chain to the "point of consumption" or "end of life", due to variations in transportation modes, distances, and the efficiency of powertrains and fuel cells. Moreover, a highly detailed scheme could be prohibitively expensive to administer, and could deter investment in low carbon hydrogen production technologies if it were too complicated. On the other hand, using a broader system boundary would estimate the emissions of a particular pathway more accurately. It is difficult to identify the optimal approach because the discrepancies in the estimates of emission intensities from different approaches are not well understood.

\begin{tabular}{|l|l|l|}
\hline \multicolumn{1}{|c|}{ Body (Country) } & \multicolumn{1}{|c|}{ Carbon Accounting Standard } & \multicolumn{1}{c|}{ Source } \\
\hline AFHYPAC (FR) & Not specified. & Not specified. \\
\hline
\end{tabular}




\begin{tabular}{|l|l|l|}
\hline BEIS (UK) & LCA (unspecified). & DECC (2015) \\
\hline CARB (USA) & CARB OPGEE model or an alternative model & CARB (2019) \\
& Ex LCA methodology approved by the & \\
\hline CERTIFHY (EU) & ISO 14044 and 14067, Annex V and Annex VI & CertifHy (2019) \\
& of the Renewable Energy Directive & \\
\hline CEN/CENELEC (EU) & ISO 14044 and 14067, Annex V and Annex VI & CEN/CENELEC (2019) \\
& of the Renewable Energy Directive & \\
\hline TÜV SÜD (DE) & ISO 14040/ 14044. & TÜV SÜD (2011a) \\
\hline
\end{tabular}

Table 7. Carbon accounting standards for different green hydrogen characterisation initiatives.

DE: Germany; EU: European Union; FR: France; UK: United Kingdom; USA: United States of America.

\subsection{Creation of an economically viable GOs scheme}

In addition to the investment in capital equipment to deliver compliant green hydrogen, participating in a scheme brings additional operating costs for data capture, auditing and trading fees (entry and transactional fees). These costs could be substantially higher for schemes with broader carbon accounting boundaries.

A green hydrogen GOs market requires the participation of several stakeholders (see Figure 3) whose roles add value but also costs. National registries can charge companies a fee for 
registering into a GO scheme. Transactional costs are influenced by the type of chain of custody (see Figure 2). A dual trading platform for hydrogen and its GOs only makes sense for the book and claim approach, as segregation and mass balance approaches trade GOs and energy together (bundled). The advantage of book and claim is the need for lower foresight and control, and hence lower costs of managing the scheme. In the UK, RE GO fees are in the range of $0.15-0.30 € / \mathrm{MWh}$, which is much lower that the wholesale cost of electricity $\left(£ 41.35 / \mathrm{MWh}^{8}\right)(\mathrm{OFGEM}, 2019)$; hence the transactional costs are likely to be sufficiently low to not affect investment decisions.

Small hydrogen producers could face high market barriers because of initial capital costs and restrictions on market entry (for example, the minimum contract size for operating in the European EEX market is $1,000 \mathrm{GOs}$, equivalent to $1 \mathrm{GWh}$ power, which could be too large at the initial stages of green hydrogen market development). A green hydrogen GOs platform would ideally allow much smaller contracts until demand were large enough to sustain larger trade volumes. New technologies such as blockchain and smart contracts could contribute to decrease these costs by enabling the aggregation of bundles under $1 \mathrm{MWh}$.

\subsection{Emission intensity threshold}

Some of the characterisation initiatives determine what can be labelled as green or lowcarbon hydrogen based on an emission intensity threshold (Table 2). However, their approaches differ based on whether they use a relative threshold, which is set relative to fossil fuel baseline emissions, or an absolute threshold. For example, the RED required biofuels to reduce emission by at least $60 \%$ compared to the equivalent fossil fuel, as this was the minimum requisite for a feedstock to be considered as renewable (European Commission,

\footnotetext{
${ }^{8}$ Day-ahead baseload contracts wholesale market - monthly average for May 2019 (GB).
} 
2009). Another approach is an absolute threshold, which could be linked to national emission targets. An absolute threshold might be steadily reduced over time as national emission targets are tightened.

Schemes that simply label hydrogen as green or not green can offer perverse incentives to producers. Instead of pursuing the cleanest technology, producers receive the same benefits by pursuing the dirtiest technology that meets the green threshold, or can produce a mix of low-carbon and high-carbon hydrogen that meets the threshold. If a more stringent intensity threshold were combined with a banding system, this could encourage producers to adapt their supply chain to the quality of hydrogen that were most profitable. A range of grades (e.g. $A, B, C, D)$ could enable a mix of hydrogen with different emission intensities and origins to be distinguished and appropriately priced. This approach could help to create a more dynamic and resilient definition of green hydrogen while the regulations, technologies, and markets mature, and could help to avoid perverse incentives while aligning hydrogen quality with policy milestones.

\subsection{Qualifying feedstocks and production technologies}

All initiatives reviewed in this study advocate their support for technology neutrality. However, the definition of green hydrogen is critical for the eligibility criteria and several initiatives limit these to renewable pathways and exclude CCS (AFHYPAC; CertifHy; TÜV SÜD; LCFS). Under the LCFS, renewable hydrogen is derived from renewable electrolysis, catalytic cracking or SMR of biomethane or thermochemical conversion of biomass, including MSW (CARB, 2018). Similarly, AFHYPAC limits pathways to just renewable electrolysis and SMR of biomethane. TÜV SÜD Standard CMS 70 adds pyro-reforming of glycerine, and could be extended for similar feedstocks such as MSW in the future (TÜV SÜD, 2011a). Since this 
standard requires biomethane and glycerine to have German certificates, the standard is in practice limited to the German market.

The eligibility of green hydrogen generated as a by-product from other processes is also dealt with in some initiatives. The way of allocating emissions can vary from allocating zero emissions or excluding these altogether, to allocating emissions as a share of the energy content of the final products. The AFHYPAC proposal allowed the production of green hydrogen as a co-product of chlor-alkali plants, when powered by renewable electricity (AFHYPAC, 2014b). CertifHy selects energy allocation; however, it highlights the difficulty to evaluate the sustainability criteria of such pathways. The RED 2 recommends the energy allocation rather than the substitution method, as it is predictable over time, minimises counter-productive incentives, and produces comparable results (European Commission, 2018). The RED 2 excludes emissions allocations to wastes and residues; however, the GHG emissions methodology include emission savings from CCS and replacement.

\section{DISCUSSION}

Typically, standards are voluntary, but can become mandatory once embedded into legislation. Under the RED 2, GOs for renewable electricity are compulsory for compliance with renewable obligations; however, GOs for renewable gases (including hydrogen) and biomethane are voluntary. The RED 2 includes the minimum details that must be included in these GOs; however, the standard specifies the technical details (e.g. carbon accounting methods; chain of custody; safety rules). Due to the differing physical characteristics of the energy vectors, different chains of custody can be put forward under RE GOs and Biomethane GOs. The characterisation of green hydrogen within a green hydrogen standard can support policy harmonisation and cross-border trade among compliant markets. The IEA (2019) 
recognises that one of the policy barriers for hydrogen scale-up is the lack of harmonisation in the certification of $\mathrm{CO}_{2}$ intensity, as well as for the benchmarks of incumbent processes that they replace. This barrier could be removed by developing an international green hydrogen standard.

An alignment between a green hydrogen standard and the law facilitates the inclusion of green hydrogen in policy instruments and avoids confusion by providing clear guidelines to all stakeholders. Characterisation initiatives should be dynamic and adaptable to changes in regulations. For example, to be consistent with the definition of renewable in the RED 2, the CertifHy standard would have to be amended to increase the GHG savings threshold to $70 \%$ by 2021 and $80 \%$ by 2026 . GOs can be used for demonstrating origin, but discrepancies between the standards, GOs schemes, and legislation can prevent GOs being used to meet renewable targets by, for example, preventing green certificates being part of government subsidy schemes.

A holistic view of hydrogen in the context of the whole energy system suggest that it is likely to have a very prominent role in the energy transition due to its flexibility and contribution to energy security (Staffell et al., 2019). Power-to-gas (P2G), gas-to-power (G2P), and gas-to-gas (G2G) energy systems are becoming more important in current energy markets as green hydrogen may be used as an input or output in power generation (P2G, G2P) and in the gas network (G2G via SMR or methanation). Evidence of market growth include G2P projects such as HPEM2GAS (€2.6m public funding), ELYOFF ( $€ 2.3 \mathrm{~m}$ public funding) or BIG HIT (€10.9m total cost), where hydrogen is used as energy storage media for energy balancing and gas supply. Other examples of the use and benefits of electrolytic hydrogen in co-firing power generation with coal or biomass have been reported by Pisa et al. (2014) and Lazaroiu et al. (2017). 
There needs to be consistency between green electricity, hydrogen and biomethane standards due to the potential bidirectional flows between different energy carriers. This is particularly relevant when dealing with RE GOs or biomethane GOs to validate the production of green hydrogen. Efficiency losses in the conversion between energy carriers may result in higher energy inputs requirements, higher carbon intensities, and the loss of eligibility. For example, hydrogen is produced from steam reforming of biomethane with an efficiency of around 74\% (Velazquez Abad and Dodds, 2017). This means that the carbon intensity of green hydrogen produced from SMR of biomethane is effectively $35 \%(1 / 0.74)$ higher than the carbon intensity of the biomethane. Therefore, the use of biomethane GOs to justify eligibility for green hydrogen production plants would not be valid unless efficiency losses were considered. It is necessary to calculate the carbon footprint of each pathway (even if default values are used) to ensure compliance.

\subsection{Definitions of green hydrogen}

In Europe, countries that are more focused on delivering GHG savings than promoting renewables, and on accelerating market uptake, tend to consider a broader definition of green hydrogen that includes fossil fuels pathways combined with CCS technologies. In contrast, countries with a greater focus on research and innovation of renewables limit eligible pathways to renewables. This suggests that standards and GOs schemes provide a more representative intuitive characterisation of green hydrogen production pathways if they use labelling terms such as "renewable hydrogen" and "non-renewable hydrogen", with the prefix "low-carbon" or "zero-carbon" when appropriate. 


\subsection{Value of green hydrogen and GOs}

The hydrogen market is growing, with niche applications becoming cost-competitive with other zero-emission technologies, or expecting to reach cost parity by 2030 . So far, renewable hydrogen produced with grid electricity is more expensive than conventional hydrogen (Figure 6) and GOs can decrease the cost differential (as the payments of GOs are received by eligible manufacturers). Subsidies of $\$ 4.82 / \mathrm{kg} \mathrm{H}_{2}, \$ 3.71 / \mathrm{kg} \mathrm{H}_{2}$ and $\$ 1.33 / \mathrm{kg} \mathrm{H}_{2}$ (excluding the additional revenue from the trade of GOs) are needed to make this pathway competitive in 2019, 2030 and 2050, respectively. However, producing renewable hydrogen via solar PV in some regions will already be cheaper than merchant prices of hydrogen produced via SMR from 2030 onwards.

The value of GOs certificates is sensitive to: (i) whether it is voluntary for disclosure or mandatory for compliance purposes; (ii) whether the market demands green tariffs; (iii) the size of the market; and, (iv) whether the scheme is compatible with complementary subsidy schemes. Policies influencing these factors will play a deciding role on the evolution of the market of green hydrogen. However, future demand for green hydrogen is uncertain if it depends on customer preferences, and if distributors do not have to meet mandatory targets. There is no agreement whether issuing GOs should be compatible with green certificates, as this is seen as a duplication of revenue streams for the same product. However, as green hydrogen GOs are voluntary, the market is very small and their value is extremely low. At the initial stages of market development, allowing double compensation of GO and other incentives could have a positive impact by encouraging market growth. In the long term, depending on the revenues generated, it could accelerate the withdrawal of public incentives for these technologies. Otherwise, if schemes such as feed-in tariffs and renewable heating incentives are extended to green hydrogen, then producers would probably choose these as 
they would be more profitable than the income obtained from the GOs market. Reduce the supply of green hydrogen.

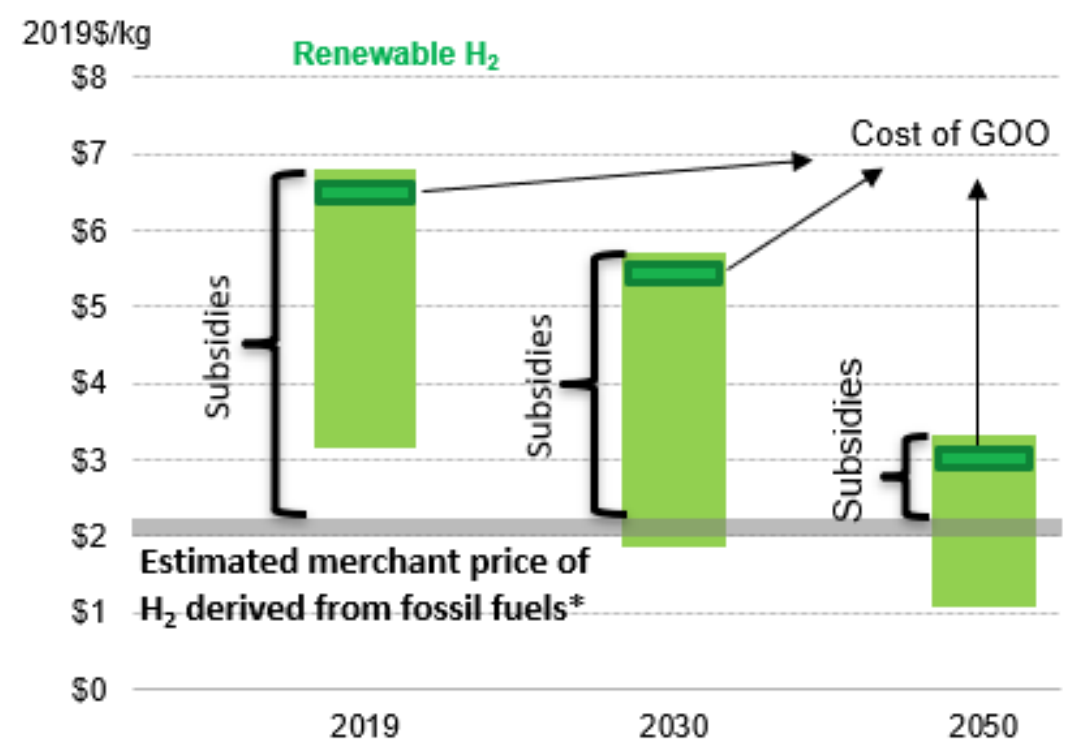

Figure 6. Forecast merchant prices of renewable hydrogen and subsidies needed to achieve cost-parity with conventional hydrogen from fossil fuels. The highest cost of each bar represents electrolytic hydrogen produced from grid power, and the lowest cost is from solar PV. Adapted from: BNEF (2019) and Velazquez Abad and Dodds (2017).

In the absence of a GO scheme, hydrogen used in flexible energy systems or industrial processes could not be certified. This limitation might be avoided if green hydrogen producers could demonstrate the link between the production of hydrogen and renewable power generation, but probably only for distributed grids where no other power sources are imported. Similar opportunities could arise if biomethane or renewable synthetic gases were used as feedstocks to produce green hydrogen on-site.

The inclusion of other social or environmental sustainability criteria (e.g. impact on biodiversity; air quality; water scarcity) should be excluded from green hydrogen standards, where these are not required by the equivalent green electricity or biomethane standards, as 
this would discriminate against green hydrogen by increasing compliance costs and the administrative burden. However, due to the lack of GHG and air quality emissions at the point of use from hydrogen-powered fuel cells, and their low noise levels, adding such additional criteria to all green energy standards would favour green hydrogen compared to biomethane. Yet air quality emissions are already regulated via other legislation in many countries. For consumers who desired stricter sustainability credentials, companies could, for example, generate an environmental product declaration according to ISO 14025 to quantify the environmental impact of a product or system or adhere to a relevant sustainability quality labelling scheme, and this could complement the information provided by a plant that were certified as producing green hydrogen.

\subsection{Trade-offs between accuracy and cost}

The higher the data accuracy expected at each stage of the supply chain and the broader the boundaries of the system, the more difficult and expensive it becomes to calculate actual hydrogen carbon emission intensities. In the EU, biofuel, bioliquid, and biomass fuel production pathways can show compliance with sustainability criterion by using default values (European Commission, 2018). These default values are conservative estimates and are likely to be higher than the actual values; while this could leave some green hydrogen producers above and outside the eligible carbon intensity threshold, for others this approach reduces their administrative burden significantly. Similar conservative default estimates could be produced for hydrogen production routes. National registries guarantee that participants in their national GOs markets meet the requirements of their green hydrogen GO scheme and ensure that the data held in the system is reliable and consistent (Figure 3). Trading platforms must avoid double selling and double counting GOs, as this would distort the market. 
Little research has been undertaken to discover the role that blockchain could play to minimise the transactional costs of GOs schemes, or the policy measures needed to adapt the incumbent system to the trade of green hydrogen GOs and compatible energy carriers (P2G, G2P, G2G). Regulatory changes allowing the issuing and bundling of smaller GOs into $1 \mathrm{MWh}$ packages could benefit distributed generators and small distributors of green hydrogen, as these could enter into the market and pay lower costs. Once the market matures and significant volumes are traded, smart meters and smart contracts could facilitate and automate trading cost-efficiently. In the meantime, an EU-wide distributed ledger technology platform for green hydrogen GOs could support national registries by improving performance, efficiency, safety, traceability, quality, integrity and reliability of the system by avoiding double counting, selling, disclosing and compensating. In this type of platform, an entry cannot be tampered with once it has been recorded, and smart contracts could automate some of the operations, reducing the possibility of human error.

\subsection{Impacts of a green hydrogen standard on customers}

It could be argued that developing green hydrogen standards contributes to increasing customer choice. Yet these initiatives could create confusion by promoting too many different hydrogen labels (e.g. brown or regular hydrogen, green hydrogen, low carbon hydrogen, blue hydrogen, etc.), given the limited awareness that the general public has about hydrogen and fuel cells technologies, their emission saving potential, and other sustainability criteria. Further research is needed to ascertain the impact that developing a green hydrogen standard might have on consumers. 


\section{CONCLUSIONS AND POLICY IMPLICATIONS}

Hydrogen could be a low-carbon alternative for parts of the energy system in which electrification is not feasible or difficult, but only if the hydrogen emissions are sufficiently low. Green hydrogen schemes provide evidence that hydrogen meets certain sustainability criteria. The main differences between green hydrogen characterisation initiatives relate to: (i) the definition of green hydrogen (e.g. reducing greenhouse gas emissions or promoting renewables); (ii) the boundaries of the system (point of production, point of use, or well-towheel basis); (iii) the chain of custody; (iv) emission intensity thresholds; and, (v) eligibility of pathways (feedstocks and production technologies). Decisions on these factors are often influenced by other national and international standards, and the legal framework in which the green hydrogen supply chain operates.

By accounting for the production and consumption of green hydrogen, guarantee of origin schemes avoid the need to use green hydrogen in closed systems and hence reduce the transactional costs when producing hydrogen from a range of low-carbon and high-carbon sources. There is much experience in Europe with renewable electricity and biomethane GOs that can be used to inform the development of green hydrogen GOs. A particular challenge is to produce a scheme that enable small hydrogen producers to participate.

Green hydrogen standards may require GOs to include carbon intensity details; however, determining those is challenging. Using default values is simpler and cheaper than using actual values, but their conservative nature might exclude some producers unnecessarily. It is not clear at present whether the footprint of hydrogen transportation and the efficiency of hydrogen consumption devices contribute significantly to the total well-to-wheel emissions of each hydrogen pathway. If they are significant, then including them in the broader system 
boundary would increase the emission uncertainty, and make it more likely that hydrogen producers would dilute the benefits of investing in lower carbon technologies.

The best approach to defining a green hydrogen standard will depend on policy aims (e.g. the types of public support that are foreseen). It will also depend on the trade-off between the accuracy of the measuring system and the cost of implementing it, which includes the breadth of the system and the need to avoid unreasonably excluding people from the market due to the scheme being too simplistic. There is a need for an in-depth analysis of hydrogen pathways, including costs and GHG emissions, to provide evidence of the implications of adopting different definitions.

A well-defined and stable policy framework is needed to reduce uncertainty and risks for producers, helping the industry to make better-informed investment decisions. Green hydrogen presents opportunities for economic growth and job creation. While international hydrogen trade might maximise economic growth in the future, it will not be possible unless consistent rules and regulations for green hydrogen standards and GOs schemes can be agreed across regions or globally.

\section{ACKNOWLEDGEMENTS}

This work was supported by the EPSRC Hydrogen and Fuel Cell Supergen Hub (grant $\mathrm{EP} / \mathrm{J} 016454 / 1)$

We want to acknowledge Dominika Klassek-Bajorek (EU Directorate-General Joint Research Centre) and Wouter Vanhoudt (Hinicio/CertfHy) for taking the time to review parts of this paper. 


\section{REFERENCES}

Aarnes, J., Eijgelaar, M., Hektor, E.A., 2018. Hydrogen as an Energy Carrier: An evaluation of emerging hydrogen value chains, Safer, Smarter, Greener. DNV-GL, Høvik.

ADEME, 2015. France Country Report. L'Agence de l'environnement et de la maîtrise de l'énergie Berlin.

AEEGSI, 2015. Direttive Per Le Connessioni Di Impianti Di Biometano Alle Reti Del Gas Naturale E Disposizioni In Materia Di Determinazione Delle Quantità Di Biometano Ammissibili Agli Incentivi, in: AEEGSI (Ed.), 46/2015/R/GAS. AEEGSI, Milano.

AFHYPAC, 2014a. Groupe de travail Garantie Origine hydrogene renouvable - livrable 1. Association francaise pour l'hydrogene et les piles a combustible.

AFHYPAC, 2014b. Groupe de travail Garantie Origine hydrogène renouvelable. Association Française pour l'Hydrogène et les Piles à Combustible, Paris.

AFHYPAC, 2016. L'hydrogène en France en 2016. Association Française pour l'Hydrogène et les Piles à Combustible, Paris.

AIB, 2017. Home. The European Energy Certificate System EECS: The Concept Retrieved 13 October, 2017, from https://www.aib-net.org/.

ARENA, 2018. Hydrogen offers significant exporting potential for Australia. Australian Renewable Energy Agency, Canberra.

ASIG, 2016. Encouragement de l'injection de biogaz. Retrieved 18 March, 2016, from http://www.gaz-naturel.ch/biogaz/encouragement-de-linjection-de-biogaz/.

Bellaby, P., Flynn, R., Ricci, M., 2012. Rapidly diffusing innovation: whether the history of the Internet points the way for hydrogen energy. Innovation: The European Journal of Social Science Research 25, 322-336. 
Bleischwitz, R., Bader, N., 2008. The Policy Framework for the Promotion of Hydrogen and Fuel Cells in Europe: a Critical Assessment. Bruges European Economic Policy (BEEP) Briefing 19/2008.

BNEF, 2019. Hydrogen: The Economics of Production From Renewables, in: BloombergNEF (Ed.), London.

BSI, 2015. BS EN 16325:2013+A1:2015. Guarantees of Origin related to energy - Guarantees of Origin for Electricity. The British Standards Institution London.

CARB, 2018. Low Carbon Fuel Standard. Attachment A. 15-Day Modificaitons., in: CARB (Ed.), Staff Report. California Environmental Protection Agency Air Resources Board, Sacramento, p. 6.

CARB, 2019. Proposed Amendments to the Low Carbon Fuel Standard Regulation and to the Regulation on Commercialization of Alternative Diesel Fuels. Final Regulation Order., in: CARB (Ed.), Staff Report. California Environmental Protection Agency Air Resources Board, Sacramento.

Castro, J., Fraile, D., Barth, F., Vanhoudt, W., Altmann, M., Weindorf, W., 2016. Technical Report on the Definition of 'CertifHy Green' Hydrogen, in: Hinicio (Ed.), Deliverables. CertifHy, Brussels.

Çelik, D., Yıldız, M., 2017. Investigation of hydrogen production methods in accordance with green chemistry principles. International Journal of Hydrogen Energy 42, 23395-23401. CEN, 2016. SFEM/WG Hydrogen workshop "Power-to-Hydrogen: key challenges and next steps". European Standardisation Retrieved 22 August, 2019, from https://ec.europa.eu/irc/en/event/workshop/workshop-power-hydrogen. 
CEN/CENELEC, 2018. What is a European Standard (EN)? . European Standardisation

$\begin{array}{llll}\text { Retrieved } & 19 & \text { February, } & \text { 2019, }\end{array}$

https://www.cencenelec.eu/standards/DefEN/Pages/default.aspx.

CEN/CENELEC, 2019, 14 February 2019. CEN - CENELEC. Sector Forum Energy Management Working Group Hydrogen. 2018 Update Report. European Standardisation Retrieved 22 August, 2019.

CEP, 2013. Definition of Green Hydrogen in the CEP, H2 Production. CEP, Hamburg, pp. 1-2.

CertifHy, 2016. Developing a European Framework for the generation of guarantees of origin for green hydrogen, CertifHy. CertfiHy, Brussels.

CertifHy, 2018. CertifHy Scheme. Dissemination level: CertifHy Stakeholder Platform, CertifHy. CertifHy, Brussels.

CertifHy, 2019. CertifHy-SD Hydrogen Criteria, CertifHy Scheme Subsidiary Document. CertifHy, Brussels.

Clark II, W.W., 2008. The green hydrogen paradigm shift: Energy generation for stations to vehicles. Utilities Policy 16, 117-129.

Clark II, W.W., Rifkin, J., 2006. A green hydrogen economy. Energy Policy 34, 2630-2639.

Clark II, W.W., Rifkin, J., O'Connor, T., Swisher, J., Lipman, T., Rambach, G., 2005. Hydrogen energy stations: along the roadside to the hydrogen economy. Utilities Policy $13,41-50$.

Clark, W.W., 2007. Partnerships in creating agile sustainable development communities. Journal of Cleaner Production 15, 294-302.

COAG, 2019, April 2019. Establishment of the Hydrogen Working Group of the COAG Energy Council. from http://www.coagenergycouncil.gov.au/publications/establishment-hydrogenworking-group-coag-energy-council.

DECC, 2015. Green Hydrogen Standard: Consultation Response, in: DECC (Ed.). DECC, London. 
DENA, 2017. About the Biogas register. Retrieved 1 September, 2019, from https://www.biogasregister.de/en/home.html?id=9.

Dincer, I., 2012. Green methods for hydrogen production. International Journal of Hydrogen Energy 37, 1954-1971.

ENTSOG, 2018, 12 December 2018. Future of Gas Infrastructure. Retrieved 25th December, 2019, from https://www.entsog.eu/future-gas-infrastructure.

ERGaR, 2017. The European Renewable Gas Registry. Retrieved 1 September, 2019, from http://www.ergar.org/.

European Commission, 2009. DIRECTIVE 2009/28/EC on the promotion of the use of energy from renewable sources and amending and subsequently repealing Directives 2001/77/EC and 2003/30/EC. European Commission, Brussels.

European Commission, 2010. Communication from the Commission on voluntary schemes and default values in the EU biofuels and bioliquids sustainability scheme (2010/C 160/01). European Commission, Brussels.

European Commission, 2014. DIRECTIVE 2014/94/EU on the deployment of alternative fuels infrastructure. European Commission, Brussels.

European Commission, 2018. Directive (EU) 2018/2001 of the European Parliament and the Council of 11 December 2018 on the promotion of the use of energy from renewable sources (recast). European Commission, Brussels.

European Commission, 2019. Fuel Quality. EU Action On-line. Retrieved 8 August, 2019, from https://ec.europa.eu/clima/policies/transport/fuel en.

European Parliament, 2007. Written declaration on establishing a green hydrogen economy and a third industrial revolution in Europe through a partnership with committed regions and cities, SMEs and civil society organisations EU, 14 May 2007. 
FCH-JU, 2014. Multi-Annual Working Plan 2014-2020. Fuel Cells and Hydrogen Joint Undertaking, Brussels.

Galich, A., Marz, L., 2012. Alternative energy technologies as a cultural endeavor: a case study of hydrogen and fuel cell development in Germany. Energy, Sustainability and Society 2, 2. Gazey, R., Ali, D., Aklil, D., 2012. Real world renewable hydrogen transport. Journal of Technology Innovations in Renewable Energy 1, 14-22.

GGCS, 2016. About your certificate. Green Gas Certification Scheme, London.

GGT, 2016. What are the benefits? Certification Scheme Retrieved 12 January, 2019, from http://greengastrading.co.uk/biomethane-certification-scheme/what-are-the-benefits/.

Goverment of Australia, Advisian, Siemens, Acil Allen, 2017. South Australian Green Hydrogen Study. A report for the Government of South Australia., Melbourne.

GSE, 2016, 3 March 2016. Garanzia d'Origine. Retrieved 18 March, 2019, from http://www.gse.it/it/Qualifiche\%20e\%20certificati/Garanzia\%200rigine/Pages/default.aspx \#0.

IEA, 2019. The Future of Hydrogen, Data \& Publications. International Energy Agency, Paris. ISO, 2019. ISO deliverables. Retrieved 5 August, 2019, from https://www.iso.org/deliverables-all.html.

Kameyama, H., Yoshizaki, K., Yasuda, I., 2011. Carbon capture and recycle by integration of CCS and green hydrogen. Energy Procedia 4, 2669-2676.

Kramer, G.J., Huijsmans, J.P.P., Austgen, D.M., 2007. Pathways to Clean and Green Hydrogen, Catalysis for Renewables. Wiley-VCH Verlag GmbH \& Co. KGaA, pp. 337-350.

Lazaroiu, G., Pop, E., Negreanu, G., Pisa, I., Mihaescu, L., Bondrea, A., Berbece, V., 2017. Biomass combustion with hydrogen injection for energy applications. Energy 127, 351-357. 
Legifrance, 2017. Décret $n^{\circ}$ 2015-1823 du 30 décembre 2015 relatif à la codification de la partie réglementaire du code de l'énergie, in: Francaise, R. (Ed.). Legifrance, Paris.

METI, 2019. Formulation of a New Strategic Roadmap for Hydrogen and Fuel Cells, in: Energy, A.f.N.R.a. (Ed.). Ministry of Economy, Trade and Industry, Tokyo.

Ministère de la Transition écologique et solidaire, 2018. Plan de déploiement de l’hydrogène pour la transition énergétique, in: solidaire, M.d.I.T.é.e. (Ed.). Département Images et Édition, Paris.

Ministry of Economic Development, 2016. Decreto Biometano, in: Development, M.o.E. (Ed.). Ministry of Economic Development, Rome.

Mol, A., Oosterveer, P., 2015. Certification of Markets, Markets of Certificates: Tracing Sustainability in Global Agro-Food Value Chains. Sustainability 7, 12258.

Moon Jae-in, 2019. Remarks by President Moon Jae-in at Presentation for Hydrogen Economy Roadmap and Ulsan's Future Energy Strategy. Office of the President, Seoul.

Naterer, G.F., Gabriel, K., Wang, Z.L., Daggupati, V.N., Gravelsins, R., 2008. Thermochemical hydrogen production with a copper-chlorine cycle. I: oxygen release from copper oxychloride decomposition. International Journal of Hydrogen Energy 33, 5439-5450.

NREL, 1995. The Green Hydrogen Report. NREL, Denver.

OFEN, 2015. Marché international du biogaz utilisé comme combustible. Office fédéral de l'énergie, Berne.

OFGEM, 2019. Electricity prices: Day-ahead baseload contracts - monthly average (GB), in: Office of Gas and Electricity Markets (Ed.). Crown, London, UK.

Ota, K.-i., Ishihara, A., Matsuzawa, K., Mitsushima, S., 2010. Hydrogen Energy System and Environmental Impact Factor. Electrochemistry 78, 970-975. 
Pisa, I., Lazaroiu, G., Prisecaru, T., 2014. Influence of hydrogen enriched gas injection upon polluting emissions from pulverized coal combustion. International Journal of Hydrogen Energy 39, 17702-17709.

Poullikkas, A., 2007. Implementation of distributed generation technologies in isolated power systems. Renewable and Sustainable Energy Reviews 11, 30-56.

Public Citizen, 2003. Statement of The Green Hydrogen Coalition. Retrieved 1 February, 2019, from http://www.citizen.org/cmep/article redirect.cfm?ID=10703.

Rifkin, J., 2002. The Hydrogen Economy. Tarcher/Putnam, New York, N.Y., USA.

Staaij, J.v.d., Bos, A.v.d., Toop, G., Alberici, S., Yildiz, I., 2012. Analysis of the operation of the mass balance system and alternatives Final Report (Task 1), Utrecht.

Staffell, I., Scamman, D., Velazquez Abad, A., Balcombe, P., Dodds, P.E., Ekins, P., Shah, N., Ward, K.R., 2019. The role of hydrogen and fuel cells in the global energy system. Energy \& Environmental Science.

State of California, 2006. Senate Bill No. 1505. Chapter 877., in: State of California (Ed.). Legislative Counsel Digest.

Study Task Force, 2018. Hydrogen Roadmap Korea. Presenting a vision, roadmap and recommendations for Korea's future hydrogen economy, Seoul.

Tada, S., Shimizu, T., Kameyama, H., Haneda, T., Kikuchi, R., 2012. Ni/CeO2 catalysts with high $\mathrm{CO} 2$ methanation activity and high $\mathrm{CH} 4$ selectivity at low temperatures. International Journal of Hydrogen Energy 37, 5527-5531.

TÜV SÜD, 2011a. Generation of Green Hydrogen, 12/2011 ed. TÜV SÜD Standard, Munich. TÜV SÜD, 2011b. TÜV SÜD Standard: Generation of Green Hydrogen. TÜV SÜD Industrie Service $\mathrm{GmbH}$. 
TÜV SÜD, 2011c. TÜV SÜD Standard: Produkt GreenMethane GM, April 2011 ed. TÜV SÜD Standard, Munich.

TÜV SÜD, 2012. TÜV SÜD Standard: Zertifizierung der Einspeisung von Biomethan in das Erdgasnetz (Erzeugung GM), December 2012 ed. TÜV SÜD Standard, Munich.

TÜV SÜD, 2014. GreenMethane, GreenMethane. TÜV SÜD,, Munich.

US EPA, 2018. Renewable Energy Certificates (RECs). Retrieved 16 April, 2019, from https://www.epa.gov/greenpower/renewable-energy-certificates-recs.

Valente, A., Iribarren, D., Dufour, J., 2017. Life cycle assessment of hydrogen energy systems: a review of methodological choices. The International Journal of Life Cycle Assessment 22, 346-363.

Velazquez Abad, A., Dodds, P.E., 2017. Production of Hydrogen A2 - Abraham, Martin A, Encyclopedia of Sustainable Technologies. Elsevier, Oxford, pp. 293-304.

Veum, K., Londo, M., Jansen, J.C., 2016. Recommendations on the establishment of a wellfunctioning EU hydrogen GoO system, CertifHy. CertifHy, Brussels.

Viesi, D., Crema, L., Testi, M., 2017. The Italian hydrogen mobility scenario implementing the European directive on alternative fuels infrastructure (DAFI 2014/94/EU). International Journal of Hydrogen Energy 42, 27354-27373.

VUE, 2016. What are the differences between the naturemade star and naturemade basic quality labels? Quality Label Retrieved 18 March, 2019, from http://www.naturemade.ch/en/unterschiede-star-und-basic.html.

Wabitsch, V., Vanhoudt, W., 2016. Overview of endorsement activities, CertifHy. CertifHy, Brussels. 
Weidong, G., Zhuoyong, Y., 2012. Research on non-grid-connected wind power/waterelectrolytic hydrogen production system. International Journal of Hydrogen Energy 37, 737740.

World Energy Council, 2019. Innovation Insights Brief - New Hydrogen Economy - Hype or Hope?, Innovation. WEC, London. 